\title{
Development of an Environmentally Friendly Biofertilizer with Keratin Degrading and Antibiotic Producing Actinomycetes
}

\author{
Lyndall M. Pettett and D. Ipek Kurtböke* \\ Institute for Sustainability, Health and Regional Engagement, University of the \\ Sunshine Coast, Maroochydore DC, Queensland 4558, Australia
}

(Received Sep. 1, 2004 / Accepted Oct. 12, 2004)

\begin{abstract}
Currently used chemical treatment of the keratinous material is the preferred method of poultry waste disposal in Australia, however it is costly, and environmental pollution problems from the chemical leachates as well as the poor nutritional quality of the end-product render this method undesirable. As the microbial community of the composting cycles have been reported to reduce the odours and pathogens of the domestic animal waste, local industries look for improved technologies of biological origin to treat poultry manure, carcasses and feather.

This study reports on an alternative method utilizing the degradative abilities of the actinomycetes in a composting system developed specifically to break down recalcitrant material and to produce a cleaner and pathogen-free endproduct with particular reference to waste usage and disposal on the Sunshine Coast Region in Queensland, Australia. Keratinolytic actinomycetes from a local poultry farm environment were isolated and used to augment the compost microflora. The inclusion of the organisms into poultry waste compost was successful in producing an odourless, pathogen free product with complete biological degradation of the feather waste in 17 days. The application of this system may improve the rapid disposal of poultry waste aswell as the public and environmental health in the Region.
\end{abstract}

\section{INTRODUCTION}

Biodegradation of intensively farmed animal waste is now viewed as an alternative avenue for creating a viable end product with visible benefits to the primary producers in environmental and economic management strategies ${ }^{1}$. A combination of specific waste products and processes produced via biological methods would lead not only to an improved consumable product but also to consumer confidence in waste management practices.

At present, the poultry industry manages waste (carcass, feather and manure) through several disposal methods. Carcass waste is generally rendered into bone and meat meal ${ }^{2}$. Feather waste is also rendered by either steam or chemical treatments to produce feather meal ${ }^{1)}$. The manure is stockpiled to be sold in either untreated or treated forms to consumers as fertilizer or disposed as landfill. Disposal pits and trench burial incineration are also common methods used for disposal of diseased mortality2). In each of these processes, however, the outcome has limitations with respect to quality, cost efficiency ${ }^{1,3)}$ as well as environmental management.

Furthermore, human pathogenic organisms are known residents of poultry farms. For example, Craven $e t$ al.$^{4)}$ concluded that the populations of Clostridium perfringens followed throughout the production and processing of the waste were at levels of $94 \%$ in the bird faecal and caecal samples and $53 \%$ on wall swabs and $29 \%$ on the workers' boots. Mallinson and Snoeyenbos ${ }^{5)}$ also showed that the untreated poultry waste provided an ideal environment for pathogenic species such as Vibrio and Salmonella to thrive. In addition, as a result of the continuous use of the glycopeptide antibiotics as a feed supplement, resistant enterococci and salmonella organisms compete with normal microflora constituting a significant human health risk ${ }^{6}$.

Investigations into feather degradation began in 1950s on alpha keratin using keratinolytic Bacillus sp. and Microsporum canis $^{7,8)}$. More recently, ranges of microorganisms were tested in vitro including Bacilli, Thermoactinomyces, and Vibrio species. They were found to be keratinolytic as well as utilizing collagen, elastin and casein ${ }^{9,10,11,12)}$. Actinomycetes were also reported to break down feathers such as Streptomyces pactum and Streptomyces albidoflavus isolated from soil showed a broad range of enzymatic activity ${ }^{10,13)}$.

Therefore, in the search of environmentally friendly processes to replace currently used environmentally hazardous ones, composting the poultry manure with indigenous microorganisms displaying keratin degrading and antibiotic producing properties might represent an alternative route.

Accordingly, the study presented here exploits the keratin degrading and antibiotic production abilities of the actinomycetes to produce a pathogen free and environmentally friendly poultry manure compost.

\section{MATERIALS AND METHODS}

\section{Actinomycete isolations and identifications}

A total of 20 poultry manure samples $(10 \mathrm{~g})$ were collect-

*Corresponding author. Phone: +61 75430 2819. E-mail: ikurtbok@usc.edu.au 
ed randomly from a local poultry farm and a composite sample was produced. Actinomycetes were isolated using serial dilution technique and starch-casein agar ${ }^{14)}$. The selected isolates were then screened for their ability to hydrolyse keratin on feather meal agar plates ${ }^{12)}$. Colonies producing clearing zones in this medium were selected for further work.

A range of morphological, biochemical studies were conducted to characterize the actinomycete isolates ${ }^{14,15,16,17)}$. Molecular sequencing of the isolates was done at the Genetic Analysis Facility, Advanced Analytical Centre, James Cook University, Townsville, Australia.

\section{Testing for enzymatic activity and production of antimi- crobial compounds}

Keratin degrading actinomycete isolates were also tested to detect a range of enzymatic activities additionally following the previously described protocols. These enzymes were $_{\text {casease }}{ }^{18)}$, hemicellulase ${ }^{14)}$, endoglucanase ${ }^{19)}$ and amylase ${ }^{14)}$.

The production of inhibitory metabolites by the actinomycete isolates was tested against the laboratory strains of Escherichia coli, Bacillus subtilis, Candida albicans, Pseudomonas aeruginosa, Staphylococcus aureus and Mycobacterium smegmatis as well as using the antibiotic resistant strains of the $E$. coli (methycillin resistant), two different strains of Enterococcus faecalis (vancomycin resistant) and $S$. aureus (vancomycin resistant) using disk diffusion assay.

In addition, to detect the survival abilities of the actinomycetes under antagonistic pressures of other indigenous microorganisms in a competitive compost environment, a basal medium adapted from Sangali and Brandelli ${ }^{12)}$ was augmented with samples of sterilized and unsterilized manure placed onto the middle of the solidifying agar plate. After solidification the plates were inoculated with the each actinomycete isolate and were then incubated at $37^{\circ} \mathrm{C}$. Growth of actinomycete isolates was monitored under competitive and uncompetitive conditions using light microscopy.

\section{Compost trials}

Actinomycete isolates, according to their ability to breakdown feathers, were placed into different groups and these groups were later used as actinomycete inoculum during composting (Tables 1 and 2).

Sterilized ryegrass seeds infested with actinomycete isolates were used to deliver the actinomycete inoculum into the manure as described by Kurtböke et al., ${ }^{21)}$ and the quantity of inoculum was $10 \%(\mathrm{w} / \mathrm{v})^{22}$.

Black polypropylene bins $(45 \mathrm{~kg})$ were used with a final compost weight of $40 \mathrm{~kg}$. The ratio of the additives applied to the manure was maintained at a $1: 1: 2$ ratio $(2.5 \mathrm{~kg}$ feather, $2.5 \mathrm{~kg}$ straw, and $5 \mathrm{~kg}$ manure $)^{23)}$. A control containing sterile ryegrass seeds $(10 \% \mathrm{w} / \mathrm{v})$ was also prepared. The timescale of the composting was 15 days with 3 days pasteurisation at the end of the treatment. Actinomycete inocu-
Table 1. Details of the actinomycete isolates used as compost inocula

\section{Compost Type 1}

USC-902, USC-906, USC-907 [Streptomyces thermosacchari (AF306657*)],

USC-901, USC-904, USC-905 [Streptomyces sp. VA26256_03 (AY436366*)],

USC-909, USC-911 [Streptomyces ambofaciens (M27245*)], USC-912 [Streptomyces sp. 060386 (AY529645*)],

USC-901, USC-904, USC-905 [Nocardioides thermolilacinus $(\mathrm{AJ} 399486 *)$ ],

USC-900, USC-903 [Actinomadura sp. S2 (AJ293715*)]

Compost Type 2

USCMP-11, USCMP-12, USCMP-13 [Saccharomonospora azurea (AFO 12792*)]

Compost Type 3

USCMP-H1 [Saccharomonospora azurea (AFO 12792*)], USC-146 [Nocardiopsis sp. 20057 (AY336518*)], USC-4 [Nonomuraea rubescens (AY039255.1*)]

Compost Type 4

All actinomycetes together

*: Accession number

Table 2. Feather degradation in different compost types used to treat poultry manure

\begin{tabular}{|c|c|c|}
\hline $\begin{array}{l}\text { Details of } \\
\text { the Compost } \\
\text { Inoculum } \\
\text { groups }\end{array}$ & $\begin{array}{l}\text { Number of } \\
\text { feathers } \\
\text { degraded }\end{array}$ & Observations on feather degradations \\
\hline $\begin{array}{l}\text { Compost } \\
\text { Type } 1\end{array}$ & $5 / 14$ & Shaft snapable in 3-4 places, barbs intact \\
\hline $\begin{array}{l}\text { Compost } \\
\text { Type } 2\end{array}$ & $4 / 14$ & $\begin{array}{l}\text { Shafts flexible, only large feathers break } \\
\text { slightly, tips showing slight degradation }\end{array}$ \\
\hline $\begin{array}{l}\text { Compost } \\
\text { Type } 3\end{array}$ & $14 / 14$ & $\begin{array}{l}\text { Breaks easily-dry inside, barbs pull out easily, } \\
\text { fine feathers turned into pulp }\end{array}$ \\
\hline $\begin{array}{l}\text { Compost } \\
\text { Type } 4\end{array}$ & $7 / 14$ & $\begin{array}{l}\text { Shaft snaps and peeled but thick sections } \\
\text { don't break, barbs come away with peeled } \\
\text { sections }\end{array}$ \\
\hline
\end{tabular}

lum was introduced at day 2 and the moisture content was set to the recommended level of $60 \%{ }^{24)}$ before the inoculation event. Compost was turned on alternate days and all sampling and testing was performed at the same time of day $(1.00 \mathrm{pm})$ to avoid bias in results, particularly in relation to external temperature drops that may impact on the outer compost edge readings.

For analytical tests to be performed in the laboratory, composite samples were produced from five $100 \mathrm{~g}$ samples collected randomly from the piles. All analysis was conducted within 2 hours of sampling for temperature ${ }^{25)}, \mathrm{pH}^{26)}$ and moisture content ${ }^{23)}$.

Malodour changes were monitored using gas chromatography (Varian Saturn 2100T GC/MS). The percentage of 
volatile solids was then calculated using standard methods ${ }^{23)}$. Analysis was performed prior to composting and after pasteurisation.

Changes in the numbers of coliform bacteria population were assessed using colony counts technique and reported as the geometric mean total coliform units per gram ${ }^{27}$.

For pasteurisation of the end product after 15 days of composting, the individual composts were placed on separate plastic bags exposed to solar radiation for 3 days ${ }^{23}$. Compost core temperature during this period was monitored at midday to ensure achieving the temperature ranges above $55^{\circ} \mathrm{C}$. Each compost sample was turned regularly to ensure a homogenous mixture during pasteurisation. At the end of pasteurisation composite samples were collected for maturation and stability analysis following guidelines from Australian and International Standards $\mathrm{s}^{23,29,30,31}$.

Bulk density was analysed from composts on day one and after pasteurisation and reported as $\mathrm{kg} / \mathrm{m}^{331}$. Particle sizegrading test was performed to determine which category it would belong (e.g. soil conditioner, mulch or fine mulch $)^{31)}$.

A Dewar self-heating test was performed using the method recommended by Brinton et al..$^{31}$. Recordings of the highest temperature achieved over the 5- day period were compared with classifications based on the European System ${ }^{31)}$.

To detect the phytotoxic effect of the compost end product, the germination index (GI) was determined on tomato seeds (cv Roma) and cress seeds ${ }^{28,30)}$, and later compared to a retail potting mix approved by Standards Australia.

Electrical conductivity and salinity of the compost end product were determined as described by Wu et al. ${ }^{26)}$. Sampling for total carbon and nitrogen was performed after the pasteurisation period with the randomly collected $10 \times 10 \mathrm{~g}$ samples from each compost and the $3 \times 1 \mathrm{~g}$ samples were drawn to form a composite from these samples. The samples were dried for 48 hours at $65^{\circ} \mathrm{C}$ in a vacuum oven. They were then ground using a ball mill (Spex 8000) and encapsulated for isotopic analysis.

Results were analysed using one-way ANOVA. The maturity and stability calculations were made on formulations as described in the literature cited.

\section{RESULTS}

\section{Identification of actinomycetes}

Following the morphological, biochemical and 16s rDNA sequencing studies, actinomycetes isolates were identified as the members of the actinomycete genera Streptomyces, Saccharomonospora, Nocardioides, Nocardiopsis and Nonomuraea (Table 1). Characteristics and the antimicrobial compound production and enzymatic abilities of the isolates are listed in Tables $3 a$ and $b$.

Although actinomycete some actinomycete isolates were identified as the same species due to the differences in their antimicrobial properties they were included in the compost inocula preparation as different strains (Tables 1 and 3b).

\section{Compost trials}

Physical changes

All composts maintained moisture content levels above control (Fig. 1a). The levelling of the moisture content between days 13 and 17 indicates stability of water holding capacity of the composts. Higher levels of moisture content in the composts inoculated with actinomycetes at 36\% (Compost Type 1), 31\% (Compost Type 2), and 34\% (Compost Type 4) were within acceptable guidelines for compost end product ${ }^{23}$. Compost Type 3 at moisture content of $22 \%$ was at the lower end of acceptability. The control displayed poor water holding capacity with the final moisture content of $11 \% \pm 4.5$.

The outer temperatures of all compost piles remained over the composting period on an average of $39^{\circ} \mathrm{C} \pm 0.3$, the average outside temperature of $34^{\circ} \mathrm{C} \pm 1.4$ (Fig. 1b) over the same period shows that biological processes within the piles were extending the thermal production to the outer areas. The highest recorded average temperature was $50^{\circ} \mathrm{C} \pm 2.3$ in the Compost Type 3 and the Compost Type 1 on day 9. The final $\mathrm{pH}$ values of the composts were between $8.6 \pm 0.05$ and $9.6 \pm 0.29$.

\section{Feather degradation and growth in competitive environ- ment}

The feather degradation was evident in all treatments. The shafts peeled apart with evidence that the inner core had been removed leaving a soft outer keratin skin (Table 2) (Fig 2a). The control of the final compost showed no degradation at all and the feathers were tough and resisted any crushing effect applied. At the end of composting, the shafts were still intact and quills remained on the barb end. Microscopic examination showed barbules intact and not bent. Whereas, in the inoculated composts, the barbules were bent at right angles every $0.5 \mathrm{~mm}$ along. These may be the sites where disulphide bonds breakage was occurring, subjected to enzymatic attack. Downy feathers in the composts disintegrated into a fine powder when crushed in the hand (Fig 2b).

All of the actinomycetes were found to grow on the plates inoculated with unsterilized manure, indicating their competitive survival ability.

\section{Malodor reduction}

The primary odorants present in the poultry manure were identified as dimethyl-disulfide (DMDS), propanol, n-pentane, n-butane, dimethyl-2,2-propane, 3-methyl pentane and methyl-cyclohexane (Figure 3).

The Compost Type 1 and Compost Type 4 had the highest reduction in volatile compounds (Table 4). The reduction of volatile peaks in the composts showing the highest decrease of volatile solids was seen on day 12 of the cycle.

\section{End-product characteristics}

According to the Dewar test all composts were classed in category IV that refers to moderately stable compost (Table $5)$.

The bulk densities increased the highest in Compost Type 1 and Compost Type 2 when comparing initial density to final density. Compost Type 1 recorded $166 \mathrm{~kg} / \mathrm{m}^{3}$ (initial) 
Table 3a. Characteristics of the actinomycete isolates

\begin{tabular}{|c|c|c|c|c|c|c|c|c|c|c|c|c|c|c|c|c|c|c|c|}
\hline Isolate ID & $\begin{array}{c}\text { USC- } \\
900\end{array}$ & $\begin{array}{l}\text { USC- } \\
901\end{array}$ & $\begin{array}{c}\text { USC- } \\
902\end{array}$ & $\begin{array}{c}\text { USC- } \\
903\end{array}$ & $\begin{array}{l}\text { USC- } \\
904\end{array}$ & $\begin{array}{l}\text { USC- } \\
905\end{array}$ & $\begin{array}{c}\text { USC- } \\
906\end{array}$ & $\begin{array}{c}\text { USC- } \\
907\end{array}$ & $\begin{array}{c}\text { USC- } \\
908\end{array}$ & $\begin{array}{c}\text { USC- } \\
909\end{array}$ & $\begin{array}{c}\text { USC- } \\
910\end{array}$ & $\begin{array}{c}\text { USC- } \\
911\end{array}$ & $\begin{array}{c}\text { USC- } \\
912\end{array}$ & $\begin{array}{c}\text { USC } \\
4\end{array}$ & $\begin{array}{c}\text { USC } \\
\text { MP- } \\
11 \\
\end{array}$ & $\begin{array}{c}\text { USC } \\
\text { MP- } \\
12 \\
\end{array}$ & $\begin{array}{c}\text { USC } \\
\text { MP- } \\
13 \\
\end{array}$ & $\begin{array}{c}\text { USC } \\
\text { MP- } \\
\text { H1 }\end{array}$ & $\begin{array}{c}\text { USC- } \\
146\end{array}$ \\
\hline \multicolumn{20}{|l|}{$\begin{array}{l}\text { Optimal } \\
\text { growth } \\
\text { range at: }\end{array}$} \\
\hline $\mathrm{pH}$ & $5-9$ & $5-7$ & $4-9$ & $5-7$ & $5-7$ & $5-7$ & $4-9$ & $4-9$ & $6-9$ & $5-8$ & $6-9$ & $5--8$ & $7-9$ & $5-8$ & $6-8$ & $7-9$ & $5-7$ & $7-8$ & $7-9$ \\
\hline $\begin{array}{l}\text { Temperature } \\
\left({ }^{\circ} \mathrm{C}\right)\end{array}$ & $\begin{array}{c}28- \\
45\end{array}$ & $\begin{array}{l}28- \\
45\end{array}$ & $\begin{array}{l}28- \\
45\end{array}$ & $\begin{array}{l}28- \\
45\end{array}$ & $\begin{array}{l}28- \\
45\end{array}$ & $\begin{array}{l}28- \\
45\end{array}$ & $\begin{array}{l}28- \\
45\end{array}$ & $\begin{array}{l}28- \\
45\end{array}$ & $\begin{array}{c}28- \\
45\end{array}$ & $\begin{array}{l}28- \\
45\end{array}$ & $\begin{array}{c}28- \\
45\end{array}$ & $\begin{array}{c}28- \\
45\end{array}$ & $\begin{array}{c}28- \\
37\end{array}$ & $\begin{array}{l}28- \\
45\end{array}$ & $\begin{array}{c}28- \\
45\end{array}$ & $\begin{array}{l}28- \\
45\end{array}$ & $\begin{array}{l}28- \\
45\end{array}$ & $\begin{array}{l}28- \\
45\end{array}$ & $\begin{array}{l}28- \\
37\end{array}$ \\
\hline $\begin{array}{l}\mathrm{NaCl} \\
\text { tolerance } \\
(\%) \text { up to }\end{array}$ & 7 & 13 & 4 & 7 & 13 & 13 & 4 & 4 & 7 & 4 & 7 & 7 & 7 & 7 & 4 & $<1$ & $<1$ & $<1$ & 7 \\
\hline \multicolumn{20}{|l|}{$\begin{array}{l}\text { Hydrolysis } \\
\text { of: }\end{array}$} \\
\hline $\begin{array}{l}\text { Feather } \\
\text { meal }\end{array}$ & + & + & + & + & + & + & + & + & + & + & + & + & + & + & - & + & - & + & + \\
\hline Casein & + & + & + & + & + & + & + & + & + & + & + & + & + & + & + & + & + & + & + \\
\hline Xylan & + & + & - & - & + & + & - & - & + & + & + & + & + & - & - & - & - & - & - \\
\hline Starch & + & + & + & + & + & + & + & + & + & + & + & + & - & + & + & + & + & + & + \\
\hline Cellulose & - & - & - & - & - & - & - & - & + & + & + & + & + & + & - & - & - & - & + \\
\hline $\begin{array}{l}\text { Indole } \\
\text { production }\end{array}$ & - & - & - & - & - & - & - & - & - & + & - & + & + & - & - & - & - & - & - \\
\hline $\begin{array}{l}\text { Nitrate } \\
\text { reduction }\end{array}$ & - & + & - & - & + & + & - & - & - & - & - & + & + & + & - & - & + & + & + \\
\hline $\begin{array}{l}\text { Gelatin } \\
\text { liquefaction }\end{array}$ & + & + & - & - & + & + & - & - & - & - & - & - & - & - & - & - & - & - & - \\
\hline
\end{tabular}

+: positive;

-: negative

and $224 \mathrm{~kg} / \mathrm{m}^{3}$ (final) bulk densities whereas the Compost Type 2 recorded $170 \mathrm{~kg} / \mathrm{m}^{3}$ (initial) and $226 \mathrm{~kg} / \mathrm{m}^{3}$ (final). The initial bulk density of Compost Type 3 and Type 4 was $194 \mathrm{~kg} / \mathrm{m}^{3}$ and only slightly increased by the end of the cycle. Carbon/Nitrogen Ratio after pasteurisation was highest in Compost 2 at 5.75, followed by Compost Type 4 at 5.27 and Compost Type 3 at 4.65. Compost Type 1 produced the lowest carbon/nitrogen ratio of 3.76 (Table 5).

Electrical conductivity in the control increased from 6.54 $\mathrm{dSm}^{-1}$ to $6.78 \mathrm{dSm}^{-1}$ during the composting cycle. Equally, the control salinity levels increased from 3.56 to 3.75 . Salinity levels were relatively equal in the composts with Compost Type 1 recording the highest at 3.11 and Compost Type 4 recording the lowest level at 2.87. Compost Type 4 also returned the lowest Electrical Conductivity at $5.29 \mathrm{dSm}^{-1}$, which corresponds with the highest recorded germination in the phytotoxicity test (Table 5).

Germination indices of the composts after pasteurisation of 3 days at $55^{\circ} \mathrm{C}$ are illustrated in Table 6. Mature compost is considered to be one where the germination percentage is over $80 \%{ }^{23)}$. Only the Compost Type 4 containing all the actinomycete isolates achieved this rating. The Compost
Type 2 showed maturity towards cress but not tomato. The same result was also obtained in the leading retailed potting mix currently used in the Sunshine Coast Region, which was used as a comparison for this test.

The particle size-grading test performed over 2 replicates categorizes the Compost Types 2, 3 and 4 as a soil conditioner with less than $20 \%$ retention of mature compost particles in the sieve. Whereas the Compost Type 1 yielded a final product with a category classed as fine mulch with over $20 \%$ mature compost particles retention during sieving. The control when sieved also fell into this category at $40 \%$ retention of the mature compost particles.

The reduction in the numbers of pathogenic bacteria at the end of the compost cycle was equivalent across all composts containing different actinomycete inocula at the end of the cycle. Initial population's geometric average was $5.3 \log 10$ $\mathrm{cfu} / \mathrm{g}$. This decreased at a rate of between 0.26 and $1.13 \mathrm{log}$ $\log ^{10} \mathrm{cfu} / \mathrm{g}$ over the composting cycle whereas the control treatments had $1.85 \log ^{10} \mathrm{cfu} / \mathrm{g}$ at day 11 and remained there until pasteurisation.

Following pasteurisation coliform reduction was significant in the Compost Type 1 whereas the Compost Type 3 
Table 3b. Antibacterial activities of the Actinomycete isolates

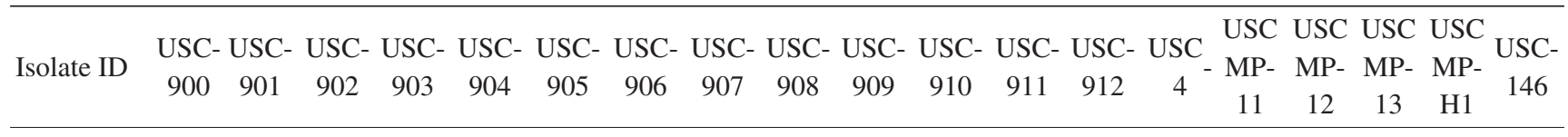

Test

organism

\begin{tabular}{|c|c|c|c|c|c|c|c|c|c|c|c|c|c|c|c|c|c|c|c|}
\hline E. coli & + & + & + & + & + & + & + & + & + & + & + & + & + & + & + & + & + & + & + \\
\hline $\begin{array}{l}\text { Bacillus } \\
\text { subtilis }\end{array}$ & - & - & - & - & - & - & - & - & - & - & - & - & - & - & + & + & + & - & - \\
\hline $\begin{array}{l}\text { Candida } \\
\text { albicans }\end{array}$ & - & - & - & - & - & - & - & - & - & - & - & - & - & - & + & + & + & - & - \\
\hline
\end{tabular}

Pseudomonas

aeruginosa

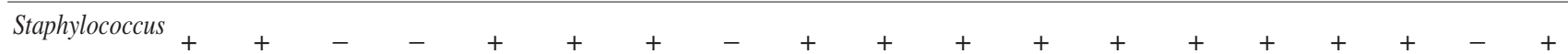

aureus

Mycobacterium

smegmatis

E.coli

(Methicillin

resistant)

Enterococcus

faecalis-1

(vancomycin

resistant)

Enterococcus

faecalis-2

(vancomycin

resistant)

S. aureus

(vancomycin + resistant)

+ : inhibitory activity is observed in the agar disk diffusion assay;

-: no inhibitory activity is observed in the agar disk diffusion assay

showing coliform presence below detection limits. The Compost Type 2 and the Compost Type 4 had minimal coliform presence ranging between $0.69 \log { }^{10} \mathrm{cfu} / \mathrm{g}$ (Compost Type 2), $0.80 \log ^{10} \mathrm{cfu} / \mathrm{g}$ in (Compost Type 4) and $0.92 \log ^{10}$ $\mathrm{cfu} / \mathrm{g}$ in the control.

\section{DISCUSSION}

Augmentation of the poultry manure with indigenous actinomycetes resulted in the production of environmentally friendly biofertilizer as well as biodegradation of feathers within 17 days. Use of indigenous actinomycetes belonging to taxa Streptomyces, Nocardiopsis, Nocardioides, Saccharmonospora and Nonomuraea species as an inoculum increased their chances of survival in a competitive environment.
In an earlier study, Tiquia and Michel ${ }^{32)}$ found that the inoculation of nonindigenous feather degrading Bacillus licheniformis and Streptomyces sp. did not enhance the composting process. Based on $\mathrm{CO}_{2}$ evolution and temperature patterns they found that the uninoculated compost community structure and degradation rate was the same as the inoculated one. Within their study there was no consideration for competitive exclusion of the two inoculated species by the existing microbial community with antagonistic properties within the compost. The inoculation of indigenous actinomycetes can be valued as a contributing factor in the success of a decreased composting time frame when compared to usually used compost cycles of 3 to 6 months ${ }^{24)}$. Furthermore, degradation of the feathers did not occur in the control compost without the actinomycete inoculum. Accordingly the rapid composting process and feather degradation 
(a)

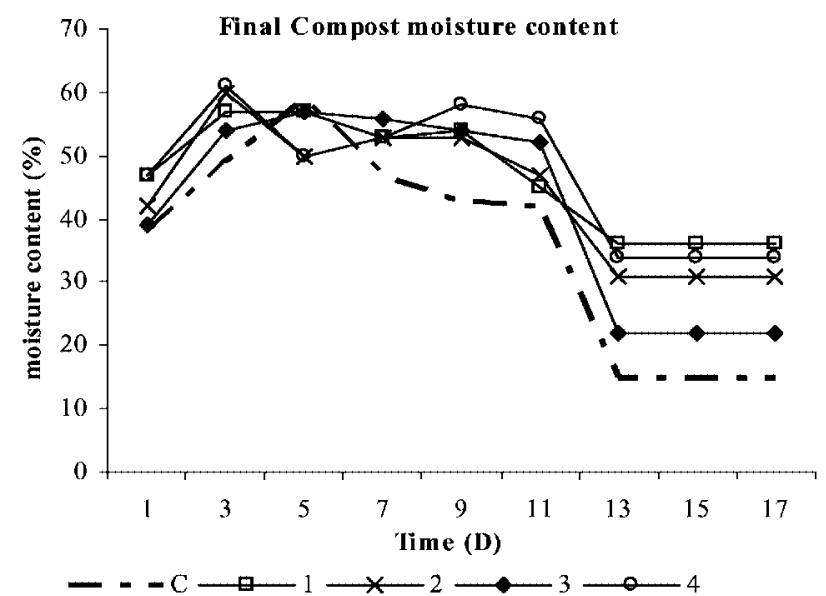

Time (D): Days

C: Control (without actinomycete inocula)

1: Compost Type 1

2: Compost Type 2

3: Compost Type 3

4: Compost Type 4

----: Represents moisture content adjustment to approximately $60 \%$. Means of 6 samples $/ 2$ replicates (b)

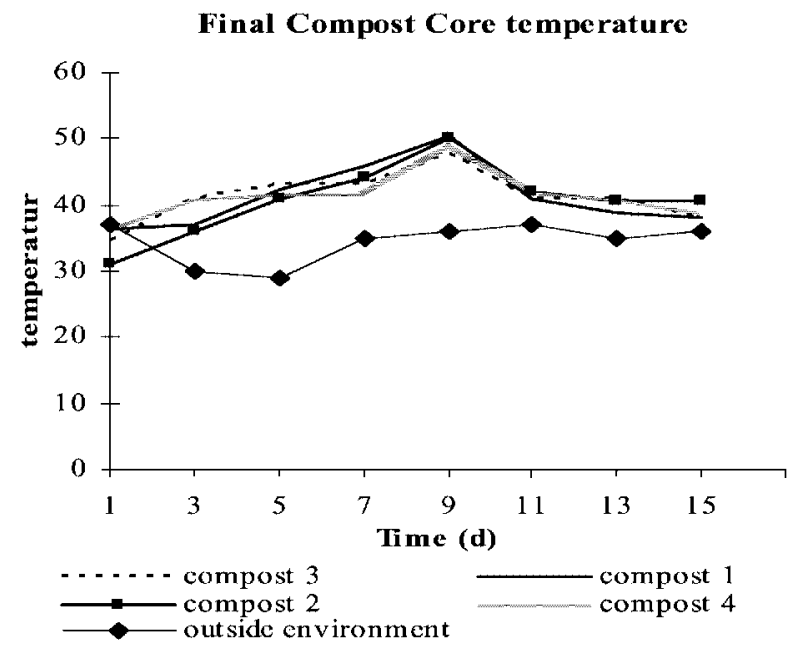

Time (D): Days

Fig. 1. Final compost moisture content (a) and core temperature values (b)

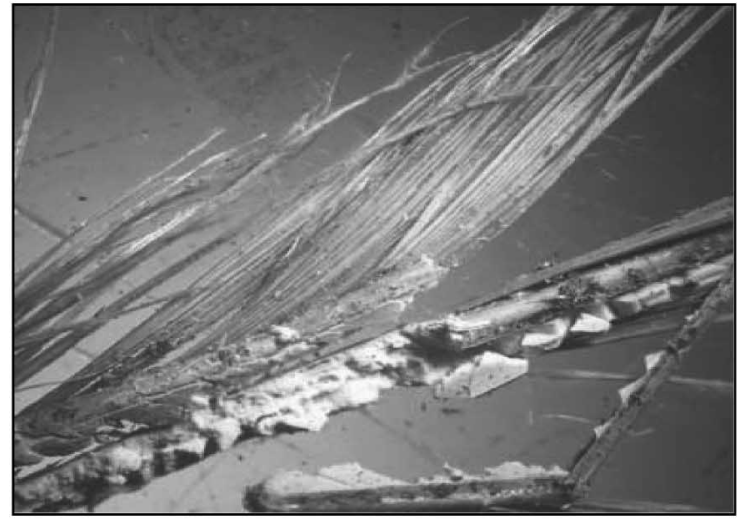

(a)

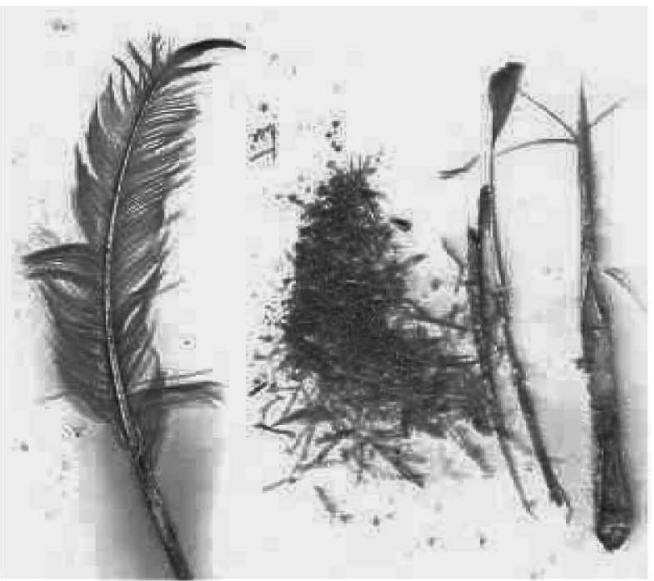

(b)

Fig. 2. Degradation of indicator feathers by actinomycete inoculum

observed in this study clearly indicates that the bioaugmentation of the compost microflora with indigenous actinomycetes speeds up the process.

The actinomycetes used in this study showed predominant growth activity between $\mathrm{pH}$ levels of 7.0 and 9.0. Findings agreed with Guerra-Rodriguez et al. ${ }^{28}$ ) who composted chestnut burr/leaf litter and poultry manure and also with Ignatova et al. ${ }^{10)}$ who conducted studies on the digestion of keratinaceous substances.
Structural differences in the barley straw after composting indicates that the actinomycete isolates used in this study might have ligninolytic activity. This finding agrees with Horwarth et al. ${ }^{33)}$ and Leifeld et al. ${ }^{34)}$.

The gas chromatography analysis showed that malodour causing compounds traced during the composting depleted well. These observations agree with the findings of Reichert et al. ${ }^{35)}$ who discovered that Pseudonocardia asaccharolytica sp. and Pseudonocardia sulfidoxydans sp. as dimethyl 


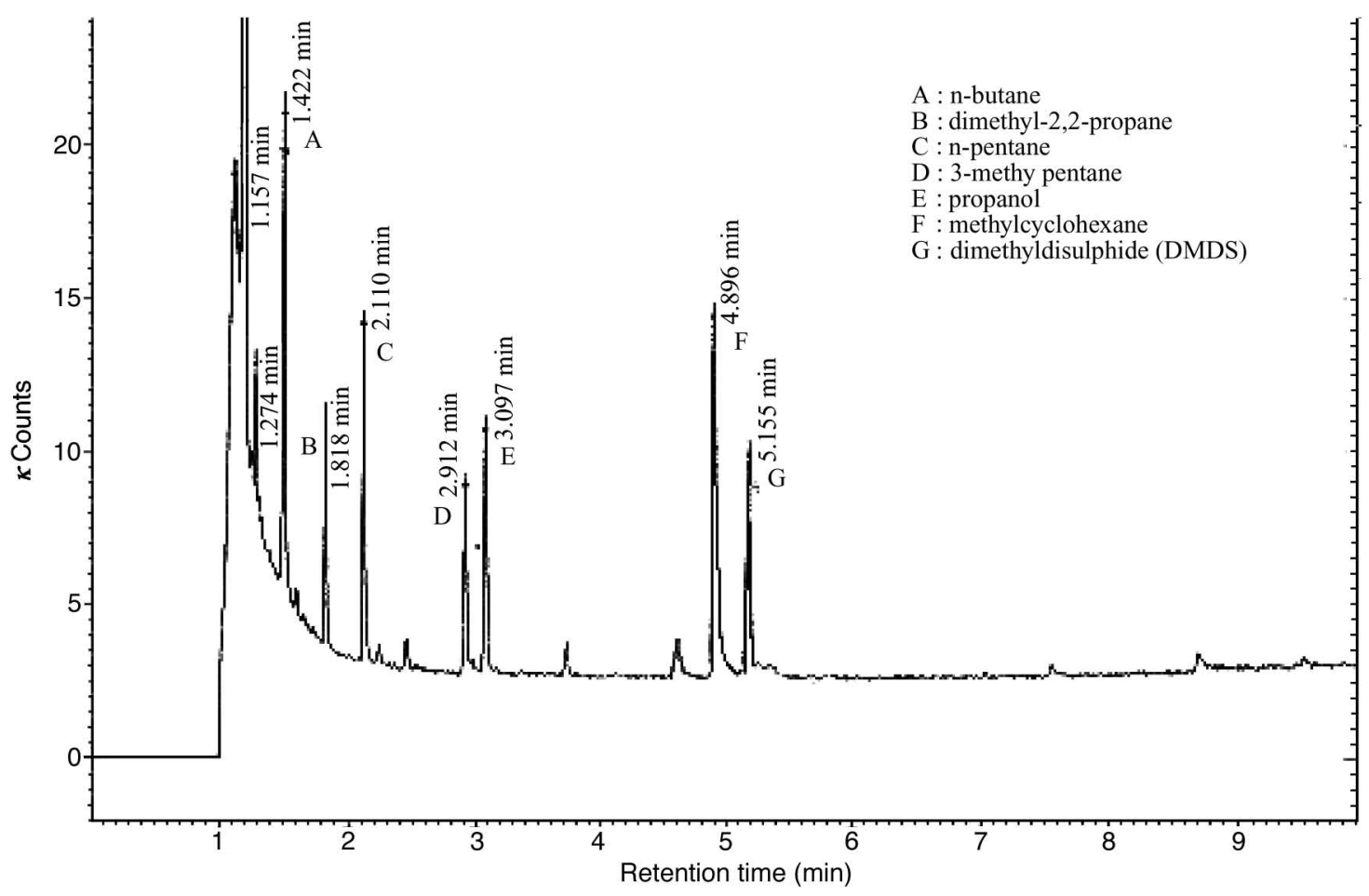

Fig. 3. Gas chromatography mass spectrometry identifying commonly detected volatile compounds in fresh poultry manure

Table 4. Detection of changes in the volatile solids before and after the composting

\begin{tabular}{lllllll}
\hline $\begin{array}{l}\text { Compost } \\
\text { Type }\end{array}$ & 1 & 2 & 3 & 4 & Control \\
\hline VS\% & Initial & 51 & 55 & 54 & 52 & 49 \\
& Final & 37 & 55 & 42 & 40 & 55 \\
\hline
\end{tabular}

VS\% change is pre and post composting cycle (including pasteurization period).

disulfide degrading actinomycetes and as well as with the findings of Ohta and Ikeda ${ }^{36}$ who described Streptomyces griseus and Streptomyces antibioticus as malodour deodorizers of pig faeces.

All composts types used in this study resulted in faecal coliform reduction under the required Environmental Protection Agency level of $1000 \mathrm{cfu} / \mathrm{g}^{23)}$ for end use. Elimination or reduction of pathogenic species and odour nuisances reduces the risks associated with disease dispersal, air quality problems, flies, vermin and scavenging animals, protection of surface and ground water.

The final level of moisture content of the composts was within guidelines ${ }^{37)}$. The dehydration rates were similar to those recorded by Hayashida et al. ${ }^{22)}$ in the treatment of pig faeces and were at the required levels for palletisation as set by Naylor and Girenes ${ }^{37)}$ for marketing purposes.

Composting using actinomycetes resulted in rapid removal of the recalcitrant feather content and the resulting composts were friable high value product that had accept-
Table 5. Maturity assessment of the final compost end-product

\begin{tabular}{lcccccc}
\hline $\begin{array}{l}\text { Compost } \\
\text { Type }\end{array}$ & $\begin{array}{c}\text { Dewar } \\
\text { temperature } \\
\text { rise above } \\
\text { ambient }{ }^{\circ} \mathrm{C}\end{array}$ & $\begin{array}{c}\text { Particle } \\
\text { size } \\
\text { grading }\end{array}$ & $\begin{array}{c}\text { Bulk } \\
\text { Density } \\
\mathrm{kg} / \mathrm{m}^{3}\end{array}$ & $\begin{array}{c}\mathrm{C} / \mathrm{N} \\
\text { Ratio }\end{array}$ & $\begin{array}{c}\text { Electrical } \\
\text { conductivity } \\
\left.(\mathrm{dS} \mathrm{m})^{-1}\right)\end{array}$ & Salinity \\
\hline 1 & 12 & 21 & 224 & 3.76 & 5.73 & 3.11 \\
2 & 13 & 16 & 226 & 5.75 & 5.67 & 3.21 \\
3 & 12 & 19 & 196 & 4.65 & 5.86 & 3.09 \\
4 & 13 & 9.25 & 218 & 5.27 & 5.29 & 2.87 \\
\hline
\end{tabular}

able land use applications. Reduction of the numbers of pathogenic bacteria and malodours was another significant achievement of the composting procedure used in this study and the phytotoxicity levels were lower than an established potting mix used as control.

Alternative poultry manure composting strategies such as the one illustrated in this study would result in the reduction of retention time in the compost cycle performed and would decrease operational costs, which would in turn significantly increase the success of on farm composting. The method used in this study might present an alternative to on farm composting to produce a community orientated and environmentally friendly facility. It would also relieve nursery facilities of environmental liability, farmers of liability and promote recycling while ensuring human and environmental health. In addition, further enzymatic studies on the keratinolytic performance of the actinomycetes in this study might lead to the biological production of feather meal. 


\section{ACKNOWLEDGEMENTS}

Authors thank Dr Peter Brooks and Dr Mark Holmes of the Faculty of Science, University of the Sunshine Coast for providing expert advice on the chemical and biochemical aspects of the study and to Dr Lynn Woodward, Genetic Analysis Facility, James Cook University, Townsville for sequence analysis of the isolates.

Lyndall Pettett gratefully acknowledges the Zonta Noosa "Women in Science" Encouragement Award.

\section{REFERENCES}

1) Kim, W. K. \& P. H. Patterson: Nutritional value of enzyme or sodium hydroxide treated feathers from dead hens. Poul. Sci. 79: 528-534, 2000

2) Environment Protection Agency: Review of on-farm disposal treatment risks and the potential for recycling of wastes produced from commercial chicken farms and processors. Consultation Draft. Prepared for the Environment Protection Agency by PPK Environment and Infrastructure Pty. Ltd., November, 1999,

(http://www.environment.sa.gov.au/epa/pdfs/chickenfarms.pdf), 1999

3) Morris, W. C. \& S. L. Balloun: Effect of processing methods on utilization of feather meal by broiler chicks. Poul. Sci. 52: 858-866, 1973

4) Craven, S. E.; N. J. Stern, J. S. Bailey \& N. A. Cox: Prevalence of Clostridium perfingens in broiler chickens and their environment during production and processing. Avi. Dis. 45(4): 887-896, 2001

5) Mallinson, E. T. \& G. H. Syoeyenbos: Salmonellosis. In Isolation and Identification of Avian Pathogens. Ed., American Association of Avian Pathologists, pp. 3-11, Kendall Hunt, Iowa, 1989

6) Collignon, P. J.: Vancomycin-resistant enterococci and use of avoparcin in animal feed: Is there a link? Med. J. Aust. 171: 144-146, 1999

7) Daniels, G.: The digestion of human hair keratin by Microsporum canis. J. Gen. Microbiol. 8: 289-294, 1953

8) Molyneux, G. S.: The digestion of wool by a keratinolytic Bacillus. Aust. J. Biol. Sci. 12: 274-281, 1959

9) Bockle, B. \& R. Muller: Reduction of disulfide bonds by Streptomyces pactum during growth on chicken feathers. Appl. Environ. Microbiol. 63: 790-792, 1997

10) Ignatova, Z.; A. Gousterova, G. Spassov \& P. Nedkov: Isolation and partial characterisation of extracellular keratinase from a wool degrading thermophilic actinomycete strain Thermoactinomyces candidus. Can. J. Microbiol. 45: 217-222, 1999

11) Lin, X.; C. G. Lee, E. S. Casale \& J. C. Shih: Purification and characterization of a keratinase from a feather-degrading Bacillus licheniformis strain. Appl. Environ. Microbiol. 58: 3271-3275, 1992

12) Sangali, S. \& A. Brandelli: Feather keratin hydrolysis by aVibrio sp. Strain Kr2. J. Appl. Microbiol. 89: 735-743, 2000

13) Bressollier, P.; F. Letourneau, M. Urdaci \& B. Verneuil: Purification and characterization of a keratinolytic serine proteinase from Streptomyces albidoflavus. Appl. Environ. Microbiol. 65: 2570-2576, 1999
14) Williams, S. T. \& E. M. H. Wellington: Actinomycetes. In Methods of Soil Analysis, Part 2. Chemical and Microbiological Properties, Eds., R.H. Miller \& D. R. Keeney, pp. 969-987, American Society of Agronomy/Soil Science Society of America, Madison, 1982

15) Cross, T.: Growth and enumeration of actinomycetes. Some guidelines. In Bergey's Manual of Systematic Bacteriology, Eds., S. T. Williams, M. E. Sharpe \& J. G. Holt, pp. 2340-2343. Williams and Wilkins, Baltimore, 1989

16) Korn-Wendish, F. \& H. J. Kutzner: The Family Streptomycetaceae. In The Prokaryotes: A Handbook on the Biology of Bacteria, Ecophysiology, Isolation, Identification, Applications Eds., A. Balows, \& H. G. Truper, pp. 921-981, Springer-Verlag, New York, 1992

17) Pridham, T. G.; C. W. Hesseltine \& R. G. Benedict: A guide for the classification of streptomycetes according to selected groups. Placement of strains in morphological sections. Appl. Microbiol. 6: 52-79, 1958

18) Ryckeboer, J.; J. Mergaert, J. Coosemans, K. Deprins \& J. Swings: Microbiological aspects of biowaste during composting in a monitored compost bin. J. Appl. Microbiol. 94: 127-137, 2003

19) Coughlan, M. P. \& F. Mayer: The cellulose-decomposing bacteria and their enzyme systems. In The Prokaryotes: A handbook on the Biology of Bacteria: Ecophysiology, Isolation, Identification, Applications, Eds., A. Balows, H. G. Trüer, M. Dworkin, W. Harder \& K.-H. Schleifer, pp. 461-502, Springer-Verlag, New York, 1992

20) Williams, S. T.; M. Goodfellow, G. Alderson, E. M. H. Wellington, P. H. A. Sneath \& M. J. Sackin: Numerical classification of Streptomyces and related taxa. J. Gen. Microbiol. 129: 1743-1813, 1983

21) Kurtböke, D. I.; M. Shankar, C. Y. Rowland \& K. Sivasithamparam: Responses of a sterile red fungus to soil types, wheat vareties and the presence of certain isolates of Streptomyces. Plant Soil 157: 35-40, 1993

22) Hayashida, S.; N. Nanri, Y. Teramoto, T. Nishimoto, K. Ohta $\&$ M. Miyaguchi: Identification and characteristics of actinomycetes useful for semicontinuous treatment of domestic animal faeces. Appl. Environ. Microbiol. 54: 2058-2063, 1988

23) Brinton, W. F.: Compost quality standards and guidelines. Woods End Research Laboratory, Inc., New York State Association of Recyclers (http://compost.css.cornell.edu/Brinton.pdf), 2000

24) Baldwin, K. R. \& J. T. Greenfield: Composting of the organic farm. URL: www.organicaginfo.org/upload/compost, 2000

25) Georgakakis, D. \& T. Krintas: Optimal use of the Hosoya system in composting poultry manure. Bioreso. Technol. 72: 227-233, 2000

26) Wu, L.; L. Q. Ma \& G. A. Martinez: Some physiological properties of microorganisms capable of deodorizing farm animal faeces. Bioreso. Technol. 60: 21-26, 2000

27) Cools, D.; G. T. van der Velde, R. Merckx \& K. J. Verhaegen: Survival of manure-derived pathogens in soil. http://www.ramiran.net/doc98/FIN-POST/COOLS.pdf, 2001

28) Guerra-Rodriquez, E.; M. Vazquez \& M. Diaz-Ravina: Dynamics of physicochemical and biological parameters during the cocomposting of chestnut burr/leaf litter with solid poultry manure. J. Sci. Food Agri. 81: 648-652, 2001

29) Arnold, P.: Report on assessing compost maturity. In A Final Report for Nova Scotia Department of Environment and 
Labour. Nova Scotia Department of Environment and Labour, Dartmouth, 2001

30) Zucconi, F.; A. Pera, M. Forte \& M. Debertoldi: Evaluating toxicity of immature compost. Biocycle 22: 54-57, 1981

31) Brinton, W. F.; E. Evans, M. L. Droffner \& R. B. Brinton: A standardized Dewar test for evaluation of compost self-heating. Biocycle 2: 2-5, 1994

32) Tiquia, S. M. \& F. C. Michel: Bacterial Diversity in Livestock Manure Composts As Characterized by Terminal Restriction Fragment Length Polymorphisms (T-RLFP) of PCRAmplified 16S rRNA Gene Sequences. In Microbiology of Composting, Eds., H. Insam, N. Riddech \& S. Klammer, pp. 65-82, Springer-Verlag, Berlin, 2002

33) Horwarth, W.R.; L.F. Elliot \& D.B. Churchill: Mechanisms regulating composting of high carbon and nitrogen ratio grass straw. Comp. Sci. Util. 3: 22-30, 1995

34) Leifeld, J.; S. Seibert \& I. Kogel-Knabner: Changes in the chemical composition of organic matter after application of compost. Eur. J. Soil Sci. 53: 299, 2002

35) Reichert K.; A. Lipski, S. Pradella, E. Stackebrandt \& K. Altendorf: Pseudonocardia asaccharolytica sp. nov. and Pseudonocardia sulfidoxydans sp. nov., two new dimethyl disulfide-degrading actinomycetes and emended description of the genus Pseudonocardia. Int. J. Syst. Bacteriol. 2: 441-449, 1998

36) Ohta, Y. \& M. Ikeda: Deodorization of pig faeces by actinomycetes. Appl. Environ. Microbiol. 36: 487-491, 1978

37) Naylor, L.M. \& H. Girenes: Making and marketing of manure to farmers. Biocycle 43: 59-61, 2002 